\title{
Arahan Peningkatan Keberlanjutan Hutan Kota di Kota Surabaya
}

\author{
Hasya Aghnia dan Ema Umilia \\ Departemen Perencanaan Wilayah dan Kota, Fakultas Arsitektur, Desain dan Perencanaan \\ Institut Teknologi Sepuluh Nopember (ITS), Surabaya, 60111 \\ e-mail: ema_umilia@urplan.its.ac.id
}

\begin{abstract}
Abstrak - Hutan Kota Surabaya merupakan salah satu ruang terbuka hijau yang belum sepenuhnya terkoordinir dengan baik dari segi sumber daya vegetasi, komunitas, dan pengelolaannya. Selain itu, luasan dan fungsi hutan kota di surabaya saat ini masih belum sesuai dengan kebutuhan dan Perda No. 15 tahun 2014 tentang Hutan kota. Tahapan penelitian ini diawali hasil content analysis adalah variabel yang berpengaruh yang terbagi dalam 3 faktor yakni sumberdaya vegetasi, komunitas dan pengelolaan. Selanjutnya, dilakukan penilaian tingkat keberlanjutan dengan menggunakan teknik skoring. Kemudian perumusan arahan peningkatan keberlanjutan hutan kota menggunakan analisis deskriptif komparatif. Hasil dari penelitian ini menunjukkan bahwa berdasarkan hutan kota berkelanjutan tinggi (hutan kota Pakal, hutan kota Balasklumprik, hutan kota Sumurwelut, dan Kebun Binatang Surabaya) berfokus pada strategi koordinasi antar dinas, kerjasama industri hijau dan warga serta peraturan yang tegas. Sedangkan berkelanjutan sedang dan rendah (hutan kota Lempung, hutan kota Sambikerep, hutan kota Gununganyar, hutan kota Jeruk, hutan kota Penjaringan Sari dan hutan kota Prapen) berfokus pada penanaman secara intensif, pendanaan secara kreatif, pembangunan fasilitas dan perekrutan tenaga kerja sesuai dengan luasan hutan kota.
\end{abstract}

Kata Kunci-Berkelanjutan, Hutan Kota, RTH

\section{PENDAHULUAN}

$\mathrm{K}$ OTA Surabaya merupakan salah satu kota metropolitan yang memperhatikan ekologi dalam penataan kota. Hal tersebut tercantum pada RPJMD 2016-2021 dengan visi "Surabaya Kota Sentosa yang berkarakter dan Berdaya Saing Global berbasis Ekologi". Ekologi dalam RPJMD tersebut mempunyai maksud untuk meningkatkan kualitas lingkungan hidup kota. Perkembangan kota menimbulkan kerusakan lingkungan yang dapat menurunkan daya dukung lahan dalam menopang kehidupan perkotaan, sehingga perlu dilakukan upaya untuk menjaga dan meningkatkan kualitas lingkungan melalui penyediaan ruang terbuka hijau yang memadai [1].

Dalam Rencana Tata Ruang Wilayah Kota Surabaya disebutkan bahwa Kota Surabaya masih kurang dalam peningkatan kualitas dari ruang terbuka hijau aktif dan pasif. Upaya yang dilakukan dalam penyediaan, pengelolaan dan peningkatan Ruang Terbuka Hijau (RTH) secara umum diarahkan optimalisasi fungsi, kualitas dan distribusi RTH publik secara proporsional di seluruh Kota Surabaya [2]. Salah satu jenis RTH yang perlu upaya pengembangan adalah hutan kota.
Hutan Kota adalah suatu hamparan lahan yang bertumbuhan pohon-pohon yang kompak dan rapat di dalam wilayah perkotaan baik pada tanah negara maupun tanah hak, yang ditetapkan sebagai hutan kota oleh pejabat yang berwenang [3]. Berdasarkan Peraturan Daerah Kota Surabaya Nomor 15 Tahun 2014 tentang Hutan Kota, persentase luas hutan kota paling sedikit 10\% (sepuluh perseratus) dari wilayah kota atau seluas 3.300 ha (tiga ribu tiga ratus hektar) dalam kurun 10 tahun. Sedangkan kini baru terdapat 48.68 hektar atau sebesar $0,01 \%$ dari ketentuan Perda Hutan Kota sehingga luasan hutan kota di Kota Surabaya masih sangat kurang [4]. Sehingga masih belum memberikan manfaat hutan kota yang optimal.

Padahal hutan kota apabila dilihat dari fungsinya dapat mengurangi terjadinya fenomena Urban Heat Island, pencemaran air tanah, rawan genangan dan banjir rob karena minimnya resapan air. Fenomena Urban Heat Island ini dipengaruhi oleh beberapa faktor yaitu persentase ruang terbuka hijau, perkerasan dan emisi karbon. Emisi karbon di Surabaya meningkat $72,97 \%$ dari 20 tahun terakhir dan perkerasan jalan meningkat $97,69 \%$ yang digunakan untuk jalan tol dan jalan utama. Kenaikan emisi karbon, perkerasan dan luas ruang terbuka hijau yang tetap menyebabkan kenaikan suhu dan perbedaan suhu antara kawasan perkotaan dan perdesaan [5]. Permasalahan hutan kota di Surabaya yang paling mendasar hingga saat ini adalah dukungan dari penentu kebijakan, dukungan finansial, dukungan masyarakat dan tenaga ahli [6]. Penelitian ini bertujuan untuk merumuskan arahan peningkatan keberlanjutan hutan kota di Kota Surabaya.

\section{METODE PENELITIAN}

Jenis penelitian yang digunakan dalam penelitian ini adalah jenis penelitian kualitatif-kuantitatif. Pendekatan yang dilakukan pada penelitian ini adalah pendekatan rasionalistik. Tahapan dalam penelitian ini yakni sebagai berikut:

\section{A. Analisis variabel berpengaruh pada peningkatan hutan kota berkelanjutan}

Variabel yang mempengaruhi peningkatan hutan kota berkelanjutan dihasilkan dari hasil sintesis tinjauan pustaka 
dan literatur yang meliputi kajian penelitian dan teori yang berkaitan dengan hutan kota berkelanjutan. Hasil sintesis tinjauan pustaka tersebut akan dikonfirmasi pada stakeholders yang telah dipilih melalui teknik pengambilan sampel purposive sampling. Melalui metode in-depth interview, stakeholders yang dipilih akan melakukan konfirmasi terkait variabel yang mempengaruhi pengembangan hutan kota berkelanjutan di wilayah penelitian.

\section{B. Menilai tingkat keberlanjutan hutan kota di Kota Surabaya}

Teknik analisis yang digunakan adalah analisis deskriptif kuantitatif dengan metode skoring yakni memberikan skor/nilai pada masing-masing variabel berdasarkan parameter tingkat keberlanjutan.

Masing-masing variabel memiliki parameter yang digunakan untuk mengukur tingkat keberlanjutan. Parameter yang digunakan dikategorikan menjadi 4 (empat) yaitu yang didefinisikan sebagai berikut.

Tabel 1.

Skala Pengukuran

\begin{tabular}{cl}
\hline $\begin{array}{c}\text { Nilai } \\
\text { Variabel }\end{array}$ & \multicolumn{1}{c}{ Kategori Parameter } \\
\hline 4 & Sangat berkelanjutan/ Berkelanjutan Tinggi \\
3 & Cukup Berkelanjutan/ Berkelanjutan Sedang \\
2 & Kurang Berkelanjutan/ Berkelanjutan Rendah \\
1 & Tidak Berkelanjutan \\
\hline \hline
\end{tabular}

Adapun untuk mengetahui nilai rentang atau interval masing-masing kategori pada penelitian ini dilakukan dengan cara sebagai berikut:

$$
\text { Interval }=\frac{\text { total nilai maksimal }- \text { total nilai minimal }}{\text { jumlah kategori }}
$$

Keterangan :

Total nilai maksimal $=$ nilai skor maksimal $\mathrm{x}$ jumlah variabel

Total nilai minimal $=$ nilai skor minimal $\mathrm{x}$ jumlah variabel

Sehingga diperoleh nilai dan kategori parameter tingkat keberlanjutan untuk hutan kota di Kota Surabaya sebagai berikut.

Tabel 2.

Skoring Penilaian Tingkat Keberlanjutan

\begin{tabular}{cl}
\hline \hline Skor Variabel & \multicolumn{1}{c}{ Kategori } \\
\hline $48,76-60$ & Berkelanjutan Optimal \\
$37,6-48,75$ & Berkelanjutan Tinggi \\
$26,26-37,50$ & Berkelanjutan Sedang \\
$15-26,25$ & Berkelanjutan Rendah \\
\hline \hline
\end{tabular}

\section{Merumuskan arahan peningkatan keberlanjutan hutan} kota Surabaya

Dalam merumuskan arahan peningkatan keberlanjutan hutan kota pada penelitian ini metode yang digunakan adalah teknik analisis deskriptif komparatif. teknik analisis deskriptif komparatif digunakan dengan cara membandingkan beberapa hasil output dari kajian kebijakan, studi literatur, dan hasil analisis (Content Analysis dan skoring) [7].

\section{HASIL DAN DISKUSI}

Pada penelitian ini wilayah administrasi yang berlokasi di Kota Surabaya terdapat 10 lokasi hutan kota yakni Hutan Kota Balas Klumprik, Hutan Kota Pakal, Hutan Kota Sumurwelut, Hutan Kota Lempung, hutan Kota Sambikerep, Hutan Kota Gunung Anyar, Hutan Kota Jeruk, Kebun Binatang Surabaya, Hutan Kota Penjaringan Sari, dan Hutan Kota Prapen.

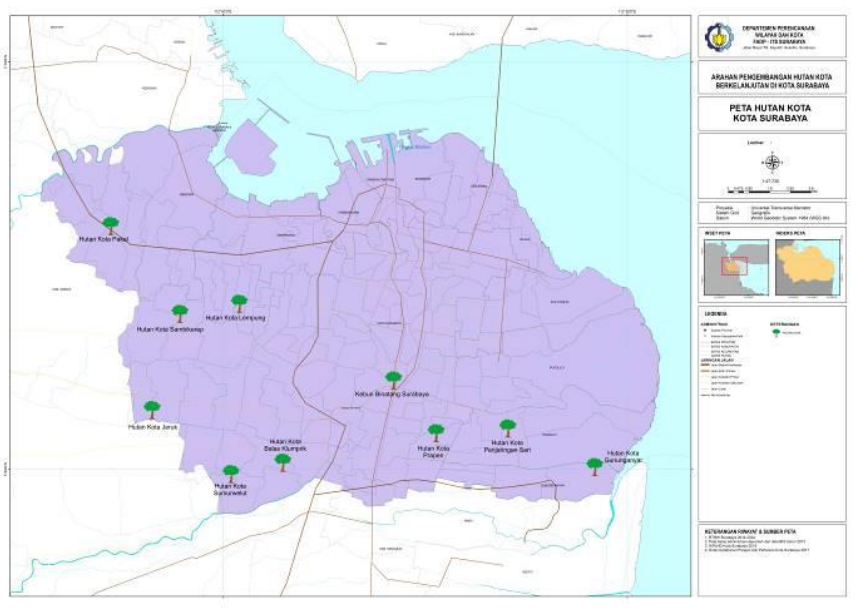

Gambar 1. Lokasi Hutan Kota di Kota Surabaya

Adapun hutan kota dan persentase setiap hutan kota dapat dilihat pada tabel berikut.

Tabel 3.

Luas Hutan Kota

\begin{tabular}{clrr}
\hline \hline No & \multicolumn{1}{c}{ Hutan Kota } & $\begin{array}{c}\text { Luas } \\
\text { (Ha) }\end{array}$ & $\begin{array}{c}\text { Persentase } \\
\text { Hutan Kota } \\
(\%)\end{array}$ \\
\hline 1 & Hutan Kota Pakal & 13 & 26.71 \\
2 & Hutan Kota Lempung & 1.92 & 3.94 \\
3 & Hutan Kota Sambikerep & 1.03 & 2.12 \\
4 & Hutan Kota Gunung Anyar & 3.2 & 6.57 \\
5 & Hutan Kota Balas Klumprik & 4.3 & 8.83 \\
6 & Hutan Kota Sumurwelut & 3.34 & 6.86 \\
7 & Hutan Kota Jeruk & 5.8 & 11.91 \\
8 & Kebun Binatang Surabaya & 15.36 & 31.55 \\
9 & Hutan Kota Penjaringan Sari & 0.3 & 0.62 \\
10 & Hutan Kota Prapen & 0.43 & 0.88 \\
& & 48.68 & 100 \\
\hline \hline
\end{tabular}

Sumber : IKPLHD Kota Surabaya (2016), Dinas Ketahanan Pangan dan Pertanian (2017)

\section{A. Variabel Berpengaruh Hutan Kota Berkelanjutan di Kota Surabaya}

Dalam melakukan proses analisis untuk mengidentifikasi variabel yang berpengaruh pada hutan kota dilakukan melalui in depth interview kemudian dianalisis menggunakan content analysis. Dari 16 variabel yang diperoleh dari sintesa tinjauan pustaka diperoleh 15 variabel yang berpengaruh berdasarkan hasil content analysis dari 7 stakeholder. Untuk itu, secara keseluruhan dapat disimpulkan bahwa karakteristik pengembangan hutan kota berkelanjutan di Kota Surabaya adalah sebagai berikut. 
1) Sumberdaya Vegetasi

Sumberdaya vegetasi berkaitan dengan target yang terkait dengan status sumber vegetasi itu sendiri dan / atau pengetahuan tentang sumber daya itu. Dalam indikator ini variabel yang berpengaruh adalah variabel tutupan kanopi, distribusi umur, diversitas vegetasi, kesesuaian vegetasi, dan vegetasi pada lahan privat.

2) Komunitas

Komunitas disini memili arti keterlibatan pemangku kepentingan yang penting di semua level, dan kolaborasi diantara mereka. Dalam indikator ini, variabel yang berpengaruh dari hasil content analysis diatas adalah

Variabel kerjasama antar dinas, kerjasama utilitas, kerjasama industri hijau, keterlibatan landholder, keterlibatan warga, pemanfaatan sumber daya. Sedangkan variabel yang tidak berpengaruh adalah kolaborasi regional.

3) Pengelolaan

Faktor pengelolaan berisi mengenai rencana, penyelenggaraan, dan kebijakan untuk meningkatkan dan mempertahankan sumber daya hutan. Sesuai dengan konten analisis diatas, maka pada indikator resources management approach variabel yang berpengaruh terhadap pengembangan hutan kota yang berkelanjutan di Kota Surabaya adalah variabel rencana manajemen kota, anggaran, kapasitas tenaga kerja, perencanaan dan implementasi penanaman, pemilihan tempat dan vegetasi, kebijakan/peraturan dan upaya daur ulang.

\section{B. Tingkat Keberlanjutan Hutan Kota di Kota Surabaya}

Dari parameter parameter skoring yang didapat dari tinjauan pustakan maka didapatkan 3 kategori hutan kota berkelanjutan yaitu berkelanjutan tinggi, sedang dan rendah. Hutan kota berkelanjutan tinggi memilik karakteristik dengan nilai yang rendah pada komunitas (kerjasama dinas, keterlibatan industri hijau, keterlibatan warga) dan pengelolaan (kebijakan/peraturan).
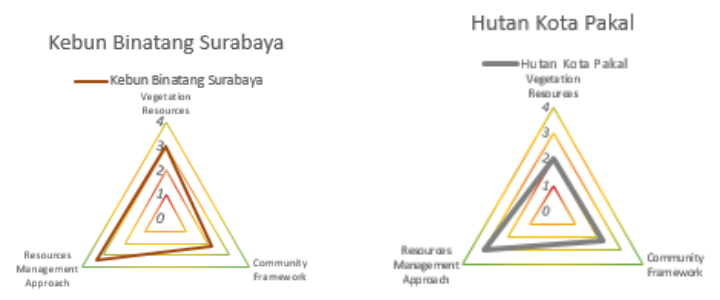
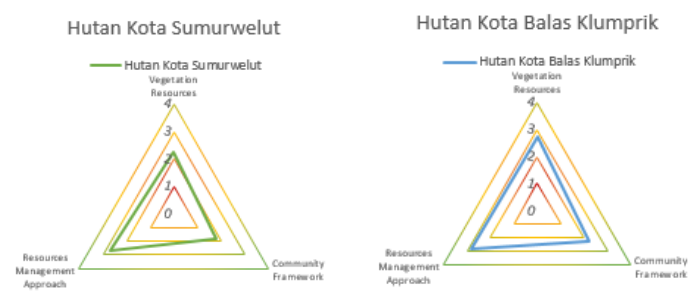

Gambar 2. Radar Chart Hutan Kota Kategori Berkelanjutan Tinggi Sumber : Hasil Analisis, 2018

Sedangkan pada hutan kota berkelanjutan sedang memiliki karakteristik dengan nilai yang rendah pada sumberdaya vegetasi (tutupan kanopi, diversitas vegetasi), komunitas (kerjasama industri hijau, kerjasama dinas, keterlibatan pemilik lahan), dan pengelolaan (anggaran,kebijakan, fasilitas, tenaga kerja, upaya daur ulang).

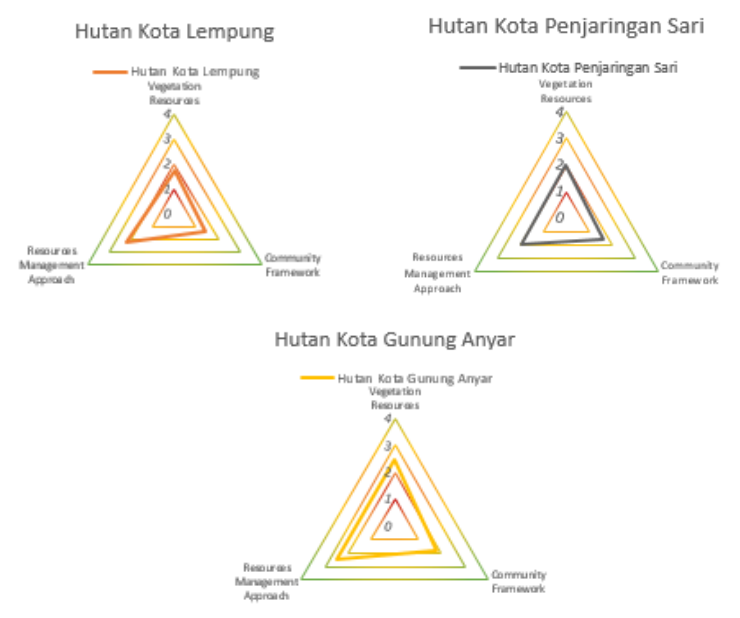

Gambar 3. Radar Chart Hutan Kota Kategori Berkelanjutan Sedang Sumber : Hasil Analisis, 2018

Pada berkelanjutan rendah memiliki nilai rendah pada setiap faktor baik itu vegetasi, komunitas dan pengelolaan.

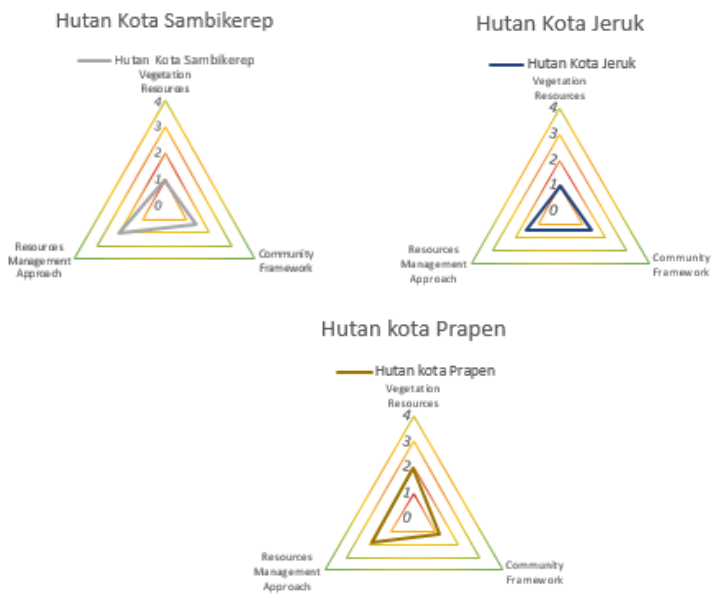

Gambar 3. Radar Chart Hutan Kota Kategori Berkelanjutan Rendah Sumber : Hasil Analisis, 2018 
Tabel 4.

Nilai Total Hasil Skoring pada Masing-masing Hutan Kota di Kota Surabaya

\begin{tabular}{clcc}
\hline \hline No & \multicolumn{1}{c}{ Hutan Kota } & Total Nilai & Kategori \\
\hline 1 & Hutan Kota Pakal & 38 & 2 \\
2 & Hutan Kota Lempung & 29 & 3 \\
3 & Hutan Kota Sambikerep & 24 & 4 \\
4 & Hutan Kota Gunung Anyar & 34 & 3 \\
5 & Hutan Kota Balas Klumprik & 39 & 2 \\
6 & Hutan Kota Sumurwelut & 38 & 2 \\
7 & Hutan Kota Jeruk & 21 & 4 \\
8 & Kebun Binatang Surabaya & 46 & 2 \\
9 & Hutan Kota Penjaringan Sari & 33 & 3 \\
10 & Hutan kota Prapen & 26 & 4 \\
\hline \hline
\end{tabular}

Sumber : Hasil Analisis, 2018

Berdasarkan hasil analisis pada tabel diatas, didapatkan total nilai dari penjumlahan skor masing-masing karakteristik tiap variabel di masing-masing desa. Dari total nilai tersebut dapat diketahui bahwa di Kota Surabaya terdapat 3 kelas kategori hutan kota yaitu kategori 2 (Berkelanjutan Tinggi), kategori 3 (Berkelanjutan sedang) dan Kategori 4 (Berkelanjutan rendah). Adapun hutan kota yang termasuk kedalam kategori 2 (berkelanjutan tinggi) yakni hutan kota Pakal, hutan kota Balasklumprik, hutan kota Penjaringan Sari, dan Kebun Binatang Surabaya dengan perolehan skoring 37,6 - 48,75. Sedangkan yang termasuk dalam kategori 3 (Berkelanjutan sedang) yaitu hutan kota Lempung, hutan kota Gununganyar, hutan kota Sumurwelut dengan besaran skoring 26,26-37,5. Dan yang terakhir kategori 4 (Berkelanjutan Rendah) yaitu hutan kota Sambikerep, hutan kota Jeruk, dan hutan kota Prapen dengan besaran skoring 15-26,25.

\section{Arahan Peningkatan Keberlanjutan Hutan Kota di Kota Surabaya}

Berikut ini merupakan arahan peningkatan hutan kota sesuai dengan kategori keberlanjutan hutan kota. Pada tahap analisis ini, variabel-variabel tersebut dikomparasikan dengan teori/best practice/peraturan perundangan untuk mengetahui bagaimana kondisi ideal dari hutan kota berkelanjutan. Perumusan arahan peningkatan hutan kota berdasarkan kategori berkelanjutan di Kota Surabaya dapat dilihat pada tabel berikut.

\section{1) Berkelanjutan Tinggi}

- Perhitungan proyeksi kanopi berdasarkan pertumbuhan tajuk sehingga dapat mengukur target tutupan kanopi di masa mendatang

- Penanaman pada lahan lahan kosong dengan memberikan jarak tanam untuk memberikan pertumbuhan yang tajuk di masa mendatang

- Peningkatan tutupan kanopi secara kualitas bukan hanya kuantitas sesuai dengan kinerja tanaman dan adaptasi paling tinggi

- Penanaman dan pendistribusian secara ideal dan seimbang dengan perbandingan remaja $40 \%$, semi mature $30 \%$, mature $20 \%$, dan tua $10 \%$ untuk menjaga kestabilan tutupan kanopi.

- Diversifikasi vegetasi sesuai dengan populasi yang terdiri tidak lebih dari 5\% dari satu spesies pohon, tidak lebih dari $10 \%$ dari satu spesies genus dan tidak lebih dari 20\% dari satu keluarga.

- Pembuatan pedoman, standar akreditasi atau strategi komunikasi bagi sektor industri hijau

- Penerapan kebijakan insentif lansung maupun tak langsung bagi landholder yang berperan dalam mendukung pengembangan hutan kota

- Peningkatan kesadaran masyarakat dalam pembangunan dan pengelolaan hutan kota secara kooperatif dengan ikut berkoordinasi rutin, menanam dan menjaga pohon baik di hutan kota maupun di lahan milik pribadi

- Pemberian sanksi dengan tegas sesuai dengan kebijakan yang berlaku bagi pihak yang dengan sengaja menurunkan fungsi hutan kota

- Pelibatan stakeholder profesional yang memiliki peran seperti peneliti, landskap, planner, aktivis lingkungan dan sebagainya untuk membantu dalam masukan dan saran yang berdampak pada vegetasi dan pengelolaan.

- Penerapan rencana pengelolaan hutan kota yang komprehensif dengan bergerak proaktif dan kreatif dalam pendanaan

- Perawatan fasilitas pendukung seperti fasilitas rekreasi, eco-edukasi, olahraga, kegiatan pelestarian dengan dilengkapi operator edukasi untuk membantu mengenalkan kepada pengunjung

- Perumusan pajak lingkungan terhadap kendaraan yang mengeluarkan emisi sehingga emisi tersebut dapat diserap oleh tanaman dalam hutan kota. Hasil pembayaran pajak tersebut dapat digunakan sebagai dana pembangunan hutan kota baru atau pengelolaan hutan kota yang sudah ada.

- Optimalisasi sarana daur ulang melalui pelaksanaan secara rutin dan pelatihan bagi tenaga kerja untuk mendukung pengelolaan hutan kota di masa mendatang

- Pemaksimalan pengolahan sampah hutan kota mulai dari pengumpulan, pengomposan dan redistribusi kompos daun

- Pengubahan pengelolaan pohon dari reaktif menjadi aktif untuk pengolahan sampah hutan kota

2) Berkelanjutan Sedang

- Peningkatan tutupan kanopi dengan penanaman dan pemeliharaan secara intensive sesuai target

- Penegakan kebijakan, rencana, program dan prosedur hutan kota untuk mendukung secara aktif tutupan kanopi 
- Peningkatan keragaman strata vegetasi baik berstrata dua maupun berstrata banyak melalui penanaman yang terdiri dari pohon, rumput juga terdapat emak, terna, liana,dan epifit.

- Peningkatan kesesuaian vegetasi melalui penggantian tanaman, pemupukan dan penyiangan sehingga dapat beradaptasi dan beraklimatisasi dengan daerah tersebut.

- Pengumpulan informasi untuk pedoman pohon perkotaaan yang sesuai sehingga dapat meningkatkan fungsi hutan kota dan landskap perkotaan

- Penguatan kerjasama secara terpadu antar dinas maupun stakeholder lain yang terlibat dalam pembangunan hutan kota (listrik, saluran air, telekomunikasi) sehingga tidak terjadi pembangunan yang tidak terorganisir atau bongkar pasang.

- Perbaikan sistem koordinasi, informasi, sinkronisasi dan sinergi antara dinas dalam bekerja sama memajukan tujuan terkait dengan masalah dan peluang hutan kota dengan memperjelas tugas, pokok dan fungsi

- Peningkatan awareness dan wawasan mengenai masalah dan peluang hutan kota kepada sektor industri hijau untuk ikut berperan dalam pengembangan hutan kota

- Pendanaan alternatif melalui kerjasama dengan perusahaan dan perbankan dengan skema pendanaan yang mudah baik untuk CSR ataupun bantuan lainnya.

- Penyediaan fasilitas pendukung seperti fasilitas rekreasi, eco-edukasi, olahraga, kegiatan pelestarian tetapi tetap memperhatikan aspek teknis, ekologis, ekonomis, sosial dan budaya setempat

- Peningkatan pengawasan dan evaluasi secara periodik terhadap kinerja staf dinas maupun outsorcing

- Sosialisasi dan pencantuman peraturan yang telah dirumuskan pada Perda hutan kota No 15 tahun 2014 pada setiap hutan kota untuk memperjelas aturan kegiatan yang dilarang

- Pembangunan sarana daur ulang untuk mengolah sampah hutan kota mulai dari daun hingga ranting menjadi pupuk kompos atau lainnya untuk mendukung kegiatan eco edukasi dan pengelolaan hutan kota secara mandiri.

3) Berkelanjutan rendah

- Peningkatan kesesuaian vegetasi melalui penggantian tanaman, pemupukan dan penyiangan sehingga dapat beradaptasi dan beraklimatisasi dengan daerah tersebut.

- Pengumpulan informasi untuk pedoman pohon perkotaaan yang sesuai sehingga dapat meningkatkan fungsi hutan kota dan landskap perkotaan
- Penegakan kebijakan, rencana, program dan prosedur hutan kota untuk mendukung secara aktif tutupan kanopi

- Pendataan atau inventarisasi secara periodik mengenai perkembangan tutupan kanopi

- Identifikasi age class untuk mengkaji potensi dan masalah dengan menerapkan penanaman dan pembaruan khusus sesuai kebutuhan

- Perawatan dan pemeliharaan berdasarkan age class vegetasi sesuai dengan prosedur

- Peningkatan keragaman strata vegetasi baik berstrata dua maupun berstrata banyak melalui penanaman yang terdiri dari pohon, rumput juga terdapat emak, terna, liana, dan epifit.

- Perbaikan sistem koordinasi, informasi, sinkronisasi dan sinergi antara dinas dalam bekerja sama memajukan tujuan terkait dengan masalah dan peluang hutan kota

- Peningkatan awareness dan wawasan mengenai masalah dan peluang hutan kota kepada sektor industri hijau untuk ikut berperan dalam pengembangan hutan kota

- Mendorong kemitraan dan koordinasi dengan swasta dan masyarakat dalam penyediaan ruang untuk pengembangan hutan kota

- Memberdayakan masyarakat sekitar sesuai dengan kompensasi pembangunan hutan kota dengan menjadikan tenaga kerja

- Sosialisasi batasan batasan dalam pemanfaatan sumber daya hutan kota

- Peningkatan pengawasan dengan cara melakukan patroli pada hutan kota secara rutin

- Pendanaan alternatif melalui kerjasama dengan perusahaan dan perbankan dengan skema pendanaan yang mudah baik untuk CSR ataupun bantuan lainnya

- Peningkatan pengawasan dan evaluasi secara periodik terhadap kinerja staf dinas maupun outsorcing

- Pengarahan dan pelatihan bagi staf maupun outsorcing sesuai dengan kebutuhan pengelolaan hutan kota

- Penyediaan kantor pengelola pada hutan kota yang memiliki tanaman maupun fungsi khusus guna meningkatkan pengawasan hutan kota

- Penyediaan fasilitas pendukung seperti fasilitas rekreasi, eco-edukasi, olahraga, kegiatan pelestarian tetapi tetap memperhatikan aspek teknis, ekologis, ekonomis, sosial dan budaya setempat

- Sosialisasi dan pencantuman peraturan yang telah dirumuskan pada Perda hutan kota No 15 tahun 2014 pada setiap hutan kota untuk memperjelas aturan kegiatan yang dilarang

- Pengadaan sarana daur ulang untuk mengolah sampah hutan kota mulai dari daun hingga ranting menjadi 
pupuk kompos atau lainnya untuk mendukung kegiatan eco edukasi dan pengelolaan hutan kota secara mandiri

\section{KESIMPULAN}

Penelitian ini menghasilkan 3 kategori hutan kota yakni berkelanjutan tinggi, sedang dan rendah. Persentase luas hutan kota berkelanjutan tinggi sebesar 73,95\% (36 Ha), berkelanjutan sedang sebesar $11,13 \% \quad(5,42 \quad \mathrm{Ha})$ dan berkelanjutan rendah sebesar 14,9\% (7,26 Ha).

Perumusan arahan peningkatan keberlanjutan hutan kota di kota Surabaya, dapat disimpulkan bahwa secara umum didapatkan beberapa fokus arahan. Berikut ini adalah fokus arahan dalam peningkatan keberlanjutan hutan kota:

1) Fokus arahan pada hutan kota berkelanjutan tinggi adalah kerjasama dinas, keterlibatan industri hijau, keterlibatan warga dan kebijakan/peraturan sehingga diperlukan koordinasi secara rutin antar dinas agar tidak terjadi tumpang tindih, mempermudah skema pembiayaan dan bantuan bagi perusahaan yang ingin melakukan CSR, mengadakan kegiatan kegiatan menarik mengenai penanaman dan pelestarian serta membuat peraturan yang tegas untuk semua hutan kota dengan pengawasan yang ketat.

2) Fokus arahan pada hutan kota berkelanjutan rendah dan sedang adalah tutupan kanopi, anggaran, kerjasama industri hijau, kerjasama dinas, keterlibatan pemilik lahan, kebijakan, fasilitas, tenaga kerja dan upaya daur ulang. Sehingga diperlukan peningkatan tutupan kanopi dengan penanaman yang intensive, penerapan pendanaan kreatif melalui biaya kebersihan atau pemanfaatan sumberdaya, pembangunan fasilitas untuk kenyamanan pengunjung, perekrutan tenaga kerja sesuai dengan luasan dan kebutuhan hutan kota serta pengadaan upaya daur ulang untuk mengurangi biaya operasional.

\section{UCAPAN TERIMA KASIH}

Penulis H.A. mengucapkan terima kasih kepada Dinas Ketahanan Pangan dan Pertanian, BAPPEKO Surabaya dan akademisi terkait yang telah menjadi sumber data yang membantu menyukseskan penelitian ini.

\section{DAFTAR PUSTAKA}

[1] J. Silas, "Ruang Terbuka Hijau Surabaya menuju Metropolitan yang Cerdas, Manusiawi dan Ekologis". Surabaya: Badan Perencanaan Pembangunan Kota (2014).

[2] Badan Perencanaan Pembangunan Kota Surabaya. RPJMD Kota Surabaya 2016-2021 (2016).

[3] Peraturan Pemerintah No. 63 Tahun 2002 tentang Hutan Kota.

[4] Badan Lingkungan Hidup, Informasi Kinerja Pengelolaan Lingkungan Hidup Daerah tahun 2016.

[5] A. Kurniati, "Factors Influencing Urban Heat Island in Surabaya". Elsavier (2016).

[6] A. Rumiati, "Harapan Masyarakat terhadap Perkembangan Sosok Pemimpin dan Masa Depan Kota Surabaya", Surabaya: ITS Press (2005).
[7] Sugiyono, Metode Penelitian Kuantitatif, Kualitatif dan R\&D, Bandung: Alfabeta (2009). 